\author{
Multidisciplinary \\ SCIENTIFIC JOURNAL OF \\ MARITIME RESEARCH
}

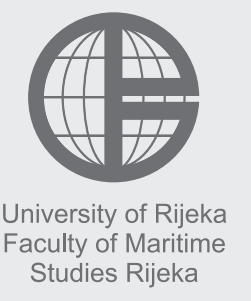

Multidisciplinarni

znanstveni časopis

POMORSTVO

\title{
Functioning of the management in ports of nautical tourism of the Republic of Croatia
}

\author{
Alen Jugović \\ University of Rijeka, Faculty of Maritime Studies Rijeka, Studentska 2, 51000 Rijeka, Croatia, e-mail: ajugovic@pfri.hr
}

\section{ABSTRACT}

Management of nautical tourism ports, by having general appropriate characteristics as well as characteristics related to business skills, can encourage development of related ports, which may result in direct and indirect impact on economy of the Republic of Croatia. For the purposes of this research work, there has been done a survey regarding management of eighteen (18) nautical tourism ports. The survey included issues such as general characteristics (gender, age), qualifications, as well as specific features like risk appetite, decision-making, use of scientific methods and similar.

The research results indicate that nautical tourism management is not prone to risk which is mostly due to management's age structure; increasing age decreases the desire for taking risks in decision-making. Management uses some group decision-making techniques, thereby it reflects the trust to lower levels in business while at the same time it increases their creativity and work motivation. Since nautical tourism is still in its nascent, the introduction of new scientific methods in decision-making could improve ports' business and give them new directions and alternative directions of perceiving business challenges.

The research paper also compares done research with previous similar surveys, but not to those that are directly related nautical tourism ports, all in order to identify changes that have occurred in management functioning over the years.
\end{abstract}

\section{ARTICLE INFO}

Original scientific paper

Received 2 May 2016

Accepted 6 June 2016

Key words:

Management

Nautical tourism

Republic of Croatia

\section{Introduction}

Nautical tourism of the Republic of Croatia is the prosperous economy branch that has to do a lot regarding development, and it has to achieve the levels of its competitors. Management of nautical tourism ports, as well as management in general, with their business decisions is the main driving force of current and future changes, therefore, this research paper presents findings obtained via questionnaire regarding management competence. The questionnaire contains questions related to general characteristics of the management itself such as age, gender, qualifications and specific features with a focus on risk appetite, type of decisions and the use of scientific methods in decision-making.

The purpose of this research work is to define risk appetite, to connect it with the age structure and to determine whether there is a certain behavior pattern. Also, this paper shows which scientific methods of nautical tourism ports management is used while decision-making and if some business aspect may be improved by using additional scientific methods. Group decision-making meth- ods are also essential item of business management since its use gives the importance to the other employees and it also examines to which extent the nautical tourism ports management uses such methods.

Research results have been compared with previous similar researches in order to spot newly formed differences regarding characteristics and functioning of the management.

\section{Reasearch analyses}

For the purposes of scientific research paper, a sampling survey ${ }^{1}$ has been done for over eighteen (18) ports of nautical tourism in the Republic of Croatia within ACI stock company system. There have been examined directors of nautical tourism ports, assistants and heads of certain sectors, all in order to obtain knowledge regarding

\footnotetext{
1 In order to make sampling survey questionnaire, the author has taken the pattern from: Sikavica, P., Bahtijarević-Šiber, F.: Management, Theory of Management and Great Empirical Research in Croatia; processing data from the questionnaire, Masmedia, Zagreb, 2004.
} 
management's dominant characteristics, meaning general characteristics and those related to their decision-making and risk appetite.

\subsection{Types of management's decisions and factors that influence their decision-making}

Management is the work process that includes others and by help of others achieves organizational goals in a changing environment with effective and efficient use of limited resources (Buble, 2006). There are three levels of management: strategic, coordinative and operational management, which correspond to different levels of managers' hierarchical structure: top level, middle level and lower level management (Zekić, 2007: 55). The processed data from this study show that more than half $(55 \%)$ of nautical tourism ports managers are placed in the middle level of management striving to top management, $28 \%$ of examinees consider themselves as the part of mid-level management, while only $17 \%$ places themselves in a lower level management.

Middle level management is focused on long-term goals and their realization, it should take care of the complete strategy and policy, as well as ensuring inputs, all in order that business runs smoothly. Managers are expected to establish a good relationship with their working environment, adapt to changes and resolve conflicts. Middle level managers should primarily deal with the tactical decisions, but that has not been proven to be accurate in this study.

As it can be seen from Chart 1, middle level management is mostly concerned with operational and routine decisions that should be reserved for the lower level management, which confirms that most nautical tourism ports do not use decentralization as a kind of the organization which is based on the transfer of responsibility and rights to decide from higher to lower levels (Jugović, Lončar, 2012: 51). It shows the confidence to the lower levels while at the same time it increases their work motivation.

It is very important for the participants of nautical tourism to spot the problems soon after they have oc- curred so they can react relatively fast. However, the quality of made decisions depends on many subjective factors such as that decision makers are informed properly and objectively, education, motivation to make decisions, responsibility for the decisions taken and adequate distribution of power and influence within the company (Sikavica, Bahtijarević-Šiber, 2004: 294). It is very difficult to accurately assess the impact of above mentioned factors on management's decision-making, but it is certainly not negligible and it should not be underestimated in any case. Chart 2 shows factors affecting the decision-making which examinees consider very important, and those which they consider less important.

Examinees have ranked good preparation of decisions and good awareness as the most important factors while decision-making. Good quality of informing directly affects the quality of made decisions. The causes of the crisis in company's business are generated in organization area and result from the wrong decisions of the highest management that might be the result of inadequate information (Dubelj, Domijan-Arneri, 2011: 191).

The examinees have rated education as an important factor, but in some smaller extent. Managers generally must have a wide range of knowledge all in order to know how to react properly in certain situations. However, knowledge rapidly becomes obsolete because new methods and new information appear every day. Therefore, the previously acquired knowledge and experience less and less assist management in solving new problems that require a certain degree of innovation. Managers must keep on with new knowledge, especially within the activities of nautical tourism since in Croatia nautical tourism has not yet reached its peak of development.

Motivation is an important factor during decision making, but respondents placed it almost on the last place of importance. Managers need to be work-motivated because they are the main drivers of growth and competitive advantage. If the manager is work-motivated, the motivation is transferred to his co-workers.

It is necessary to work more intensively on decentralization of the decisions ie., the inclusion of company's

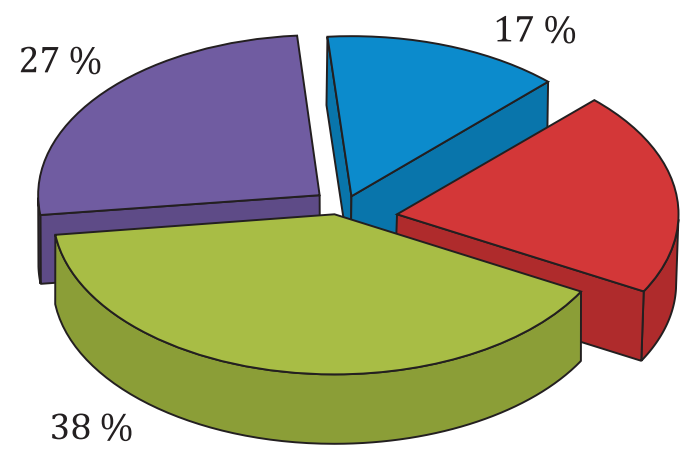

$18 \%$

strategic (17\%) $\square$ tactical (18\%) $\square$ operational (38\%) $\square$ routine (27\%)

Chart 1 Types of decisions 


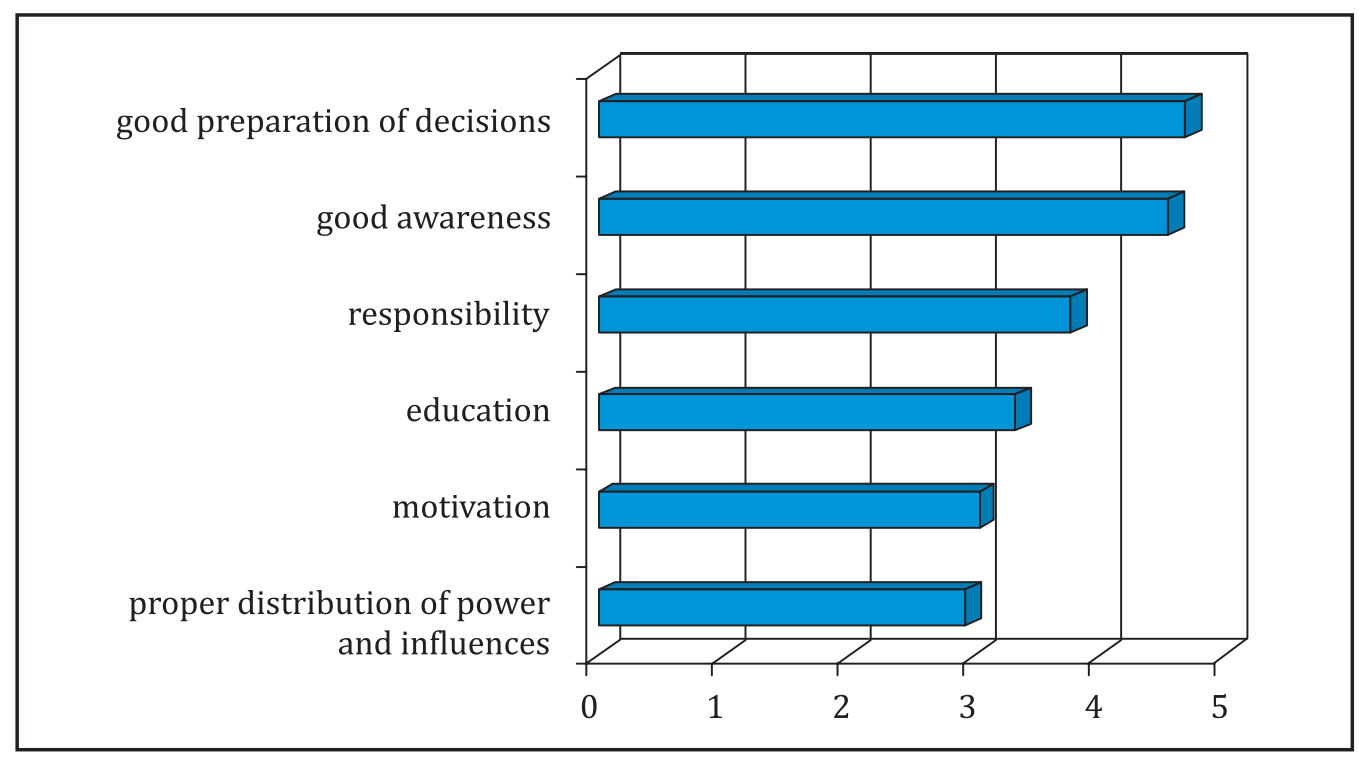

Chart 2 Impact on decision-making

lower levels in decision-making since the objective quality of management's decisions and their acceptance by subordinate staff that takes decisions into action, come into a conflict (Zekić, 2007: 259). Examinees have placed the proper power distribution and influence at the bottom of the list. The above menitoned is a bad indicator because any managerial level should act on their own problems and solve given tasks. However, previous analysis (Chart 1) has confirmed that nautical tourism managers do not operate by the rules of power distribution and influence. There is been proved that nautical tourism managers do not deal with those matters which are at their respective levels of management, but deal with the decisions and activities that should be reserved for the lower levels.

\subsection{Risk appetite and the use of scientific methods in decision-making}

Decisions regarding safety, risk and uncertainty are made in different circumstances. In terms of safety, decisions are made in a familiar environment and the probability of occurrence of certain events is known. Management controls all the aspects and conditions that affect decision-making.

Decisions made in safe conditions are mostly routine decisions and should be reserved for the lower levels of management. In this research, examinees believe they carry out $74 \%$ of their decisions in safe conditions and considering that this is mostly middle and senior management, this decisions are certainly not on their level of business. This kind of decision-making is carried out in situations where the structure of the environment is familiar as well as the probability of occurrence of certain events (Zekić, 2007: 263) and the results should be tactical decisions. Decision making with fewer information and less certainty is practiced by only $10 \%$ of examinees. In nautical tourism ports this kind of decision-making is carried out in a completely unfamiliar environment where the probability of the occurrence of certain events is unknown. Decisions taken in such environment are mostly strategical.

The propensity or aversion to risk is related to man's nature, but it must also be associated with the position in the organization. As already mentioned above, the participants of the survey are members of middle or senior management and the nature of their work imposes a certain level of risk. But, on the other hand, the majority of examinees are not prone to risk (55\%) and most are in the age group of 51-60 years. All examinees who are in age group of 61 and over have strongly identified themselves as not prone to risk. Only one respondent said that he was ready to take the risk in the business and all the consequences that derive from it, and he belongs to the younger age group, ie. from 31 to 40 years. The respondents in the age group of 41-50 are equally not prone to risk, or partly prone to risk. The results show that senior managers generally are not prone to risk and try to avoid it and reduce it to a minimum level. Furthermore, the survey proved that most managers in nautical tourism are in the senior age group; $72 \%$ of respondents are in the age group of 51-60 and 61 and over, which consequently means that the risk appetite in nautical tourism management is very small. Strategic level managers should be more prone to risks and deal with outcomes of such situations because the path to effective business means coping with risk, meaning, the awareness that proper risk management contributes not only to preserving business, but also creating added value for the business (Krstić, Đorđević, 2012: 153). Otherwise, nautical tourism could regress in business.

Risk must be managed, this means it must be approached skillfully, analytically and critically by using appropriate methods and techniques, selectively and with 
appropriate company's risk policy. The level of using scientific methods by nautical tourism ports management has been examined by the survey (questionnaire). Chart 4 compares managers' educational level and the methods applied while the decision-making.

Nautical tourism ports managers having university or higher education mostly use operational research that provides information, conclusions and results on daily basis. Simulation method is in second place and is the most common among managers with secondary education. This method is based on the development of the model which simulates future acting of the organization and is commonly used to predict the effects of changes in the environment because it is a very dynamic factor. Only two examinees having university education used game theory during collecting information and making decisions. The above mentioned method is used in conflict situations or partially conflict situations, and its aim is to determine the most favorable behavior of all participants whose actions are mutually caused. The remaining four methods (econometric model, Osborne model of creativity, decision tree and assessment and experience) are used by only $3 \%$ respondents, meaning one respondent for each method.

Mentioned data suggest the conclusion that scientific approach to decision-making of nautical tourism ports management is too narrow, but it is a business that does not have such a great need for application of scientific

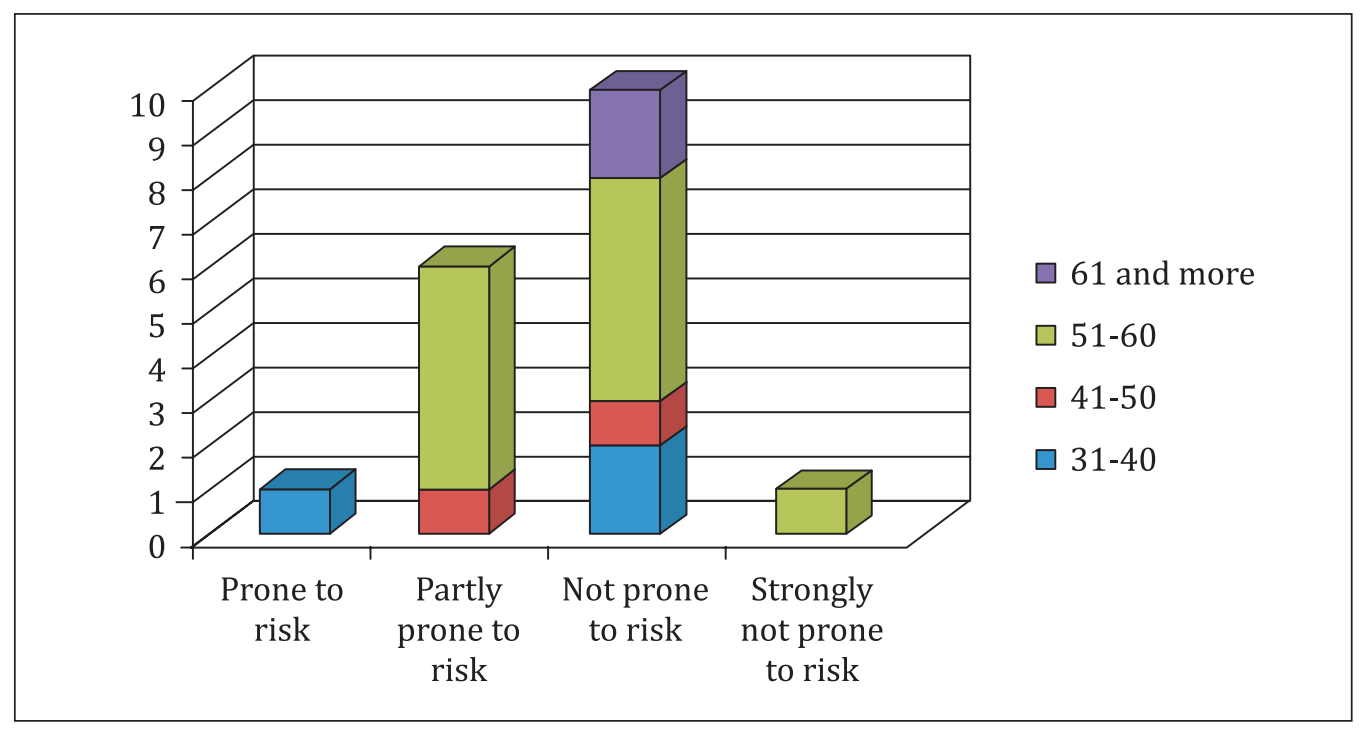

Chart 3 Comparing risk - appetite and managers' age

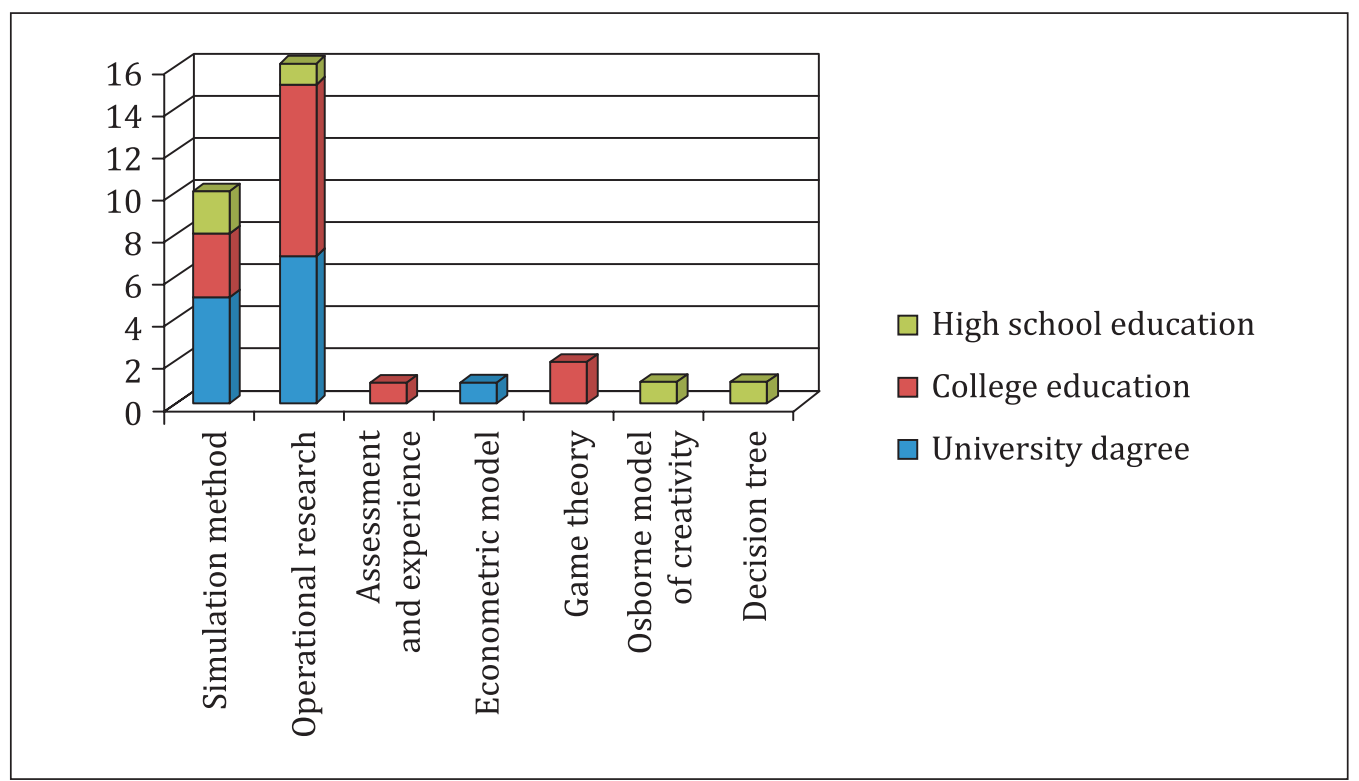

Chart 4 Comparing managers' educational level and the methods applied while the decision-making 


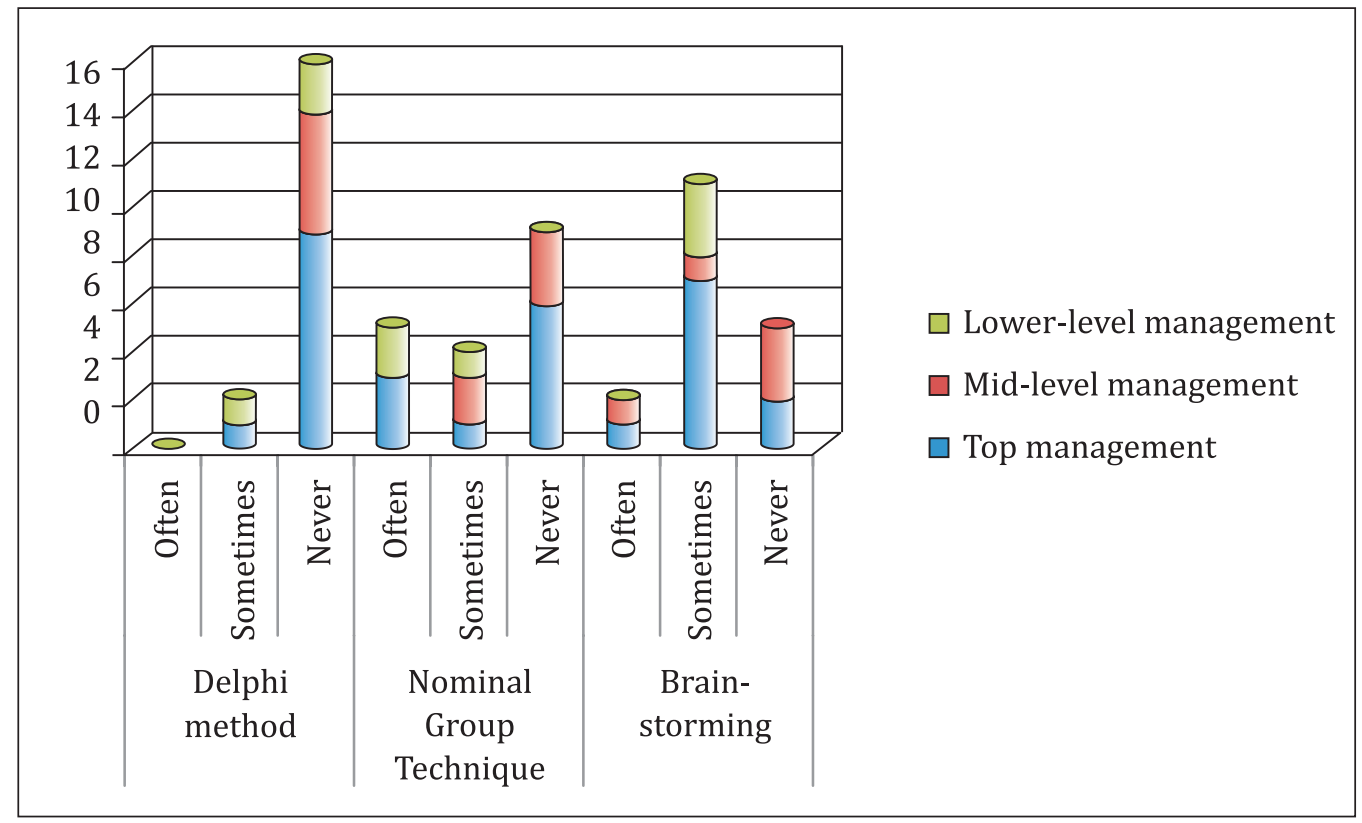

Chart 5 Frequency of using group decision-making techniques according to management levels

methods. But, as in any business and therefore in nautical tourism as well, new ways of research and reasoning can help in perceiving the problem from a different angle and give new directions and alternatives for decision-making.

Group decision-making techniques and the use of scientific methods can be of a great help to managers during decision-making. Group decision-making dominates over individual decision-making, and it is often used to make strategic decisions that require more knowledge and experience. The frequency of using group decision-making techniques by nautical tourism ports managers has been examined and related to the management level in which they are not in; the results are shown in the Chart 5.

The most commonly used method is brainstorming method; 11 examinees said that they use this technique sometimes, while two respondents in higher management levels use it often. Most mid-level managers never use brainstorming as group decision-making technique while members of the lower management sometimes use it. Brainstorming is decision-making technique based on intensive discussion and debate between group members; members generate versions of problem solutions, which is a very positive aspect of the business because the rest of the company is included and participates in decision-making (Sikavica, Bebek, Skoko, Tipurić, 1999: 170).

Nominal Group Technique is designed to encourage each member to contribute with the ideas and it encourages member's individual creativity (Sikavica, Bebek, Skoko, Tipurić, 1999: 171). Individuals generate ideas, ideas are evaluated, and finally, the best idea is selected as the problem solution. This technique is almost never applied by top level and middle level management, while the lower management often applies it. This technique is most effective while making important decisions whereas all participants of the group are included in the discussion. These two mentioned techniques can be of great benefit, because if more people work together creativity will certainly be at a higher level and it will be easier to solve the problem, while doing so, employees' opinion will be evaluated as important. Therefore, it is surprising that brainstorming is never being used by five examinees, and Nominal Group Technique by nine examinees.

Delphi method is group decision-making technique based on achieving consensus among experts by using a series of questionnaires (Sikavica, Bebek, Skoko, Tipurić, 1999: 172). Decision-making process is very similar to Nominal Group Technique, the difference is only in the fact that group members do not meet in one place. The above mentioned method is poorly represented in nautical tourism management, only two examinees use it sometimes, one of them is a higher level and one lower-level management member.

\section{Comparing research results with similar researches done in Croatia}

Analysis of relevant material related to operation of nautical tourism ports management of the Republic of Croatia, meaning, managers who operate them, indicate that such concrete researches do not exist. In regard to the research of management's operation in other industries, there is a small number of scientific papers in Croatia, and one of the most important scientific papers dealing with this issue is research of Sikavica and Bahtijarević-Šiber done in 2004 over 50 companies having various activities all over Croatia. Survey results found that the managerial level where analyzed managers are placed is mostly upper middle level (50\%), while the highest and middle have $25 \%$ each. Accordingly, managers' decisions should be mostly tactical and strate- 
Table 1 Comparing dominant management characteristics in 2004 and 2014

\begin{tabular}{|l|l|l|}
\hline \multicolumn{1}{|c|}{ Characteristics } & \multicolumn{1}{|c|}{$\begin{array}{c}\text { Questionnaire done by Sikavica and } \\
\text { Bahtijarević-Šiber (2004) }\end{array}$} & \multicolumn{1}{c|}{$\begin{array}{c}\text { Questionnaire done by the author } \\
\text { (2014) }\end{array}$} \\
\hline Age & Between 41 and 50 & Between 51 and 60 \\
\hline Top management level & Between 41 and 50 & Between 51 and 60 \\
\hline Management level & Middle & Middle \\
\hline Profession & Economic & Economic \\
\hline Educational background & University qualifications & Higher education \\
\hline Decisions & Operative & Operative \\
\hline Quickness of detecting problems & In the moment of occurrence & In the moment of occurrence \\
\hline $\begin{array}{l}\text { Factors influencing decision- } \\
\text { making }\end{array}$ & $\begin{array}{l}\text { Good and professional preparation of decisions and } \\
\text { being properly informed }\end{array}$ & $\begin{array}{l}\text { Good and professional preparation of decisions and } \\
\text { being properly informed }\end{array}$ \\
\hline Risk appetite & Partly & No \\
\hline Used scientific methods & Operational research, simulation method & Operational research, simulation method \\
\hline
\end{tabular}

Source: Sikavica, P., Bahtijarević-Šiber, F.: Menadžment, Teorija menadžmenta i veliko empirijsko istraživanje u Hrvatskoj; obrada podataka iz ankete (Management, Theory of Management and Great Empirical Research in Croatia; processing data from the questionnaire)

gic; however, research has shown that managers mostly deal with operational decisions (42\%) which indicates low decentralization and confidence in its collaborators, ie. unwillingness to delegate authority to lower levels. The same conclusion was also obtained by examining nautical tourism management, where the managers have declared that they are mostly concerned with operational and routine decisions, and strategic and tactical to a much lesser extent.

The study of Sikavica and Bahtijarević-Šiber concluded that $45 \%$ of managers had noticed a problem at the time of its occurrence, and this was also the case with nautical tourism managers. This is considered to be a positive fact, because it is easier to manage the problems if they are detected at the beginning. Once the problems have been noticed, it is necessary to operate them adequately and the examinees have concluded that the most important factors influencing the decision-making are good professional preparation of the decisions and objective awareness. In nautical tourism ports management, the situation is exactly the same. While decision-making and running business, managers expose themselves to the business risks. If they want to advance the business, they should be at least partly prone to risk, as it is case of managers of 50 Croatian companies. $43 \%$ of them think that they are partly prone to risk, while $32 \%$ are not prone to risk. In nautical tourism management situation is worse since $55 \%$ of them stated that they were not prone to risk which may withdraw the negative consequences for business. Furthermore, the scientific methods used by managers while decision-making are similar to those used by managers examined by Sikavica and Bahtijarević-Šiber and to those used by nautical tourism ports managers. Operational research and simulation are most commonly used methods, which points to the fact that managers have very narrow scientific approach to decision-making and there should be made an effort to educate them about other scientific methods and their application which would consequently lead to better business results.

Among other important researches, it is necessary to point out a research among managers in hotel companies done in 2012 by Perica Vojinić PhD. Research results have been published in a paper under the title "Attitude towards risks taking of managers employed in Croatian hotel industry". Testing has proven that hotel companies managers are more prone to modify risk than choosing between safe and risky alternatives (Vojinić, 2012: 329), while managers of nautical tourism ports are not prone to risk and seek to avoid it.

Research done over nautical tourism ports management shows similarities with the questionnaire results carried out by Sikavica and Bahtijarević-Šiber. However, there are certain differences in the average age of managers which has increased over the last decade. Managers have become more reluctant to risk and this may drag bad consequences for the business since managers put themselves at risk while deciding if they want to advance the business.

\section{Conclusion}

For Croatia, nautical tourism represents economy's new development path and it is expected a lot from a management which deals with the development and operation of nautical tourism, therefore, its knowledge and experience must be transferred into practice. Croatian nautical tourism is still developing and has not used its full potential yet. Nautical tourism management must make better efforts to take advantages of the Republic of Croatia in order to point itself out among the competition. 
Nautical tourism ports management should constantly work on defining environmental effects, studying opportunities and threats imposed and respond to risks that occur in business. Application of new scientific methods and techniques regarding group decision making could help in doing that. The age structure of nautical tourism managers is one of the reasons why managers are not prone to new working methods.

When comparing the similar research of Sikavica and Bahtijarević-Šiber carried out over the management of 50 Croatian companies, the conclusion is that over the last decade the management characteristics have not changed significantly. However, there are certain differences in the age structure where the average age of management has increased and there are also differences in risk appetite whereas managers are becoming more reluctant to risk.

Research conclusions indicate that nautical tourism management usually does not use decentralization as a management measure and mainly middle and upper level managers deal with operational and repetitive activities, and with strategic and tactical measures only in a smaller extent. In general, nautical tourism managers are not prone to risk, and this could result with demotion in business and nautical tourism development since almost always a greater chance of success is associated with a higher risk; therefore, future research of nautical tourism management should focus on risk analysis of nautical tourism and suggestions for successful risk management as an element of business excellence.

\section{References}

[1] Buble, M.: Osnove menadžmenta (Fundamental Management), Sinergija nakladništvo, Zagreb, 2006.

[2] Dubelj, N.: Domijan-Arneri, I.: Rizici nastupa krize u poslovanju poduzeća morskoga brodarstva (The risks of company management crises in marine industry), Naše more, Vol. 58, No. 5/6, Dubrovnik, 2011.

[3] Jugović, Lončar, Jolić: Mogući modeli upravljanja županijskim morskim lukama u RH (Possible models of county sea management in the Republic of Croatia), Pomorstvo: Scientific Journal of Maritime Research, Vol. 26, No. 1, Rijeka, 2012.

[4] Krstić, J.; Đorđević, M.: Interna kontrola i upravljanje rizikom poduzeća - od tradicionalnog do revidiranog COSO modela (Internal audit and managing company's risk - from traditional to revised COSO model), Ekonomske teme, Vol. 50, No. 2, Niš, 2012.

[5] Sikavica, P., Bahtijarević-Šiber, F.: Menadžment, Teorija menadžmenta i veliko empirijsko istraživanje u Hrvatskoj (Management, Theory of Management and Great Empirical Research in Croatia; processing data from the questionnaire), Masmedia, Zagreb, 2004.

[6] Sikavica, P., Bebek, B., Skoko, H., Tipurić, D.: Poslovno odlučivanje (Business decision-making), Informator, Zagreb, 1999.

[7] Vojinić, P.: Stav prema riziku menadžera zaposlenih u hrvatskim hotelskim poduzećima (Attitude towards risks taking of managers employed in Croatian hotel industry), Ekonomski vjesnik: časopis Ekonomskog fakulteta u Osijeku, Vol. No. 2, Osijek, 2012.

[8] Zekić, Z.: Menadžment: Poduzetnička tehnologija (Management - entrepreneurial technology), Ekonomski fakultet $\mathrm{u}$ Rijeci, Rijeka, 2007. 